\title{
ANALYSIS OF THE CATFISH (Clarias sp.) VALUE CHAIN AND ITS PROBLEMS IN BOGOR, INDONESIA
}

\author{
Asep Bulkini \\ School of Business Bogor Agricultural University, Indonesia \\ E-mail: Asbulkini21@gmail.com
}

Arif Satria

Faculty of Human Ecology, Indonesia Bogor Agricultural University, Indonesia

E-mail: arif.satria@gmail.com

Heti Mulyati

Faculty of Economics and Management, Indonesia Bogor Agricultural University, Indonesia

E-mail: hmulyati@gmail.com

Submission: 07/02/2017

Revision: 24/02/2017

Accept: 27/07/2017

\section{ABSTRACT}

Catfish is one of the leading freshwater commodities stipulated by the Ministry of Marine Affairs and Fisheries (KKP) of the Republic of Indonesia. The annual production target of catfish continues to increase every year. This study aims to analyze the actors and the value chain map of catfish, problems in the value chain of catfish, and the strategies to improve the value chain. This research was conducted by survey method using questionnaire instrument. The survey was done by using purposive sampling technique to 23 catfish farmers, 7 catfish wholesalers, 5 catfish retailers, and 5 catfish processors in Bogor Regency. In this study,there are 4 channels of the value chain of catfish from the production to the consumer. The four actors who are involved in the value chain, namely farmer, wholesaler, retailer, and processor. The constraints along the value chain consist of three aspects: pre-production, production, and postharvest. Pre-production problems include the quality of seeds, high price of feed, and lack of capital. 
Problems on production are the weather, fish mortality, and social security. Problems facing post-production cover price instability and lack of bargaining power of farmers. Proposed up-grading strategies to improve the competitiveness are strengthening partnership among farmers,strengthening partnerships between farmers and other strategic partners (traders, and feed companies).

Keywords: value chain, catfish, farmers

\section{INTRODUCTION}

Aquaculture is one of the fishery sub-sectors that has good prospects in Indonesia. The growth of aquaculture is greater than the capture fisheries. Aquaculture sector production has increased more than 10-times from 1.2 million tons to 13.7 million tons from 2003 to 2013.

While the fishery only grew 0.24 times from 4.6 million tons to 5.8 million tons (MINISTRY OF MARINE AFFAIRS AND FISHERIES, 2015). The growth of aquaculture opens opportunities in the labor market. The number of households of aquaculture business according to the Agricultural Census 2013 reached more than 1.18 million households (CENTRAL BUREAU OF STATISTICS, 2016).

One of aquaculture commodities which has a good prospect is catfish (Clarias $s p$.). Catfish is one of freshwater superior commodities in addition to golden fish, nile tilapia, hypothalmus, and gouramy. Based on the data of Ministry of Maritime Affairs and Fisheries (KKP), the national production of catfish from 2010-2014 continued to increase for more than 100 thousand tons per year.

The national production of catfish in 2010 was 242 thousand tons and increased to 679 thousand tons in 2014 . The growth of national production of catfish from $2010-2014$ was as much as $180.5 \%$ with continuous growth per year as much as $38.9 \%, 30.7 \%, 23.3 \%$, and 24.9\%. Ministry of Marine Affairs and Fisheries through the Directorate General of Aquaculture (DGA) will continue to improve the production of catfish. In the Strategic Design Planning of DGA from 2015 to 2019, the production of catfish is targeted to grow as much as 1.1 million tons in 2015 until become 1.8 million tons in 2019. The growth in every year is targeted to be as much as $13.8 \%$ (DGA, 2015). 
INDEPENDENT JOURNAL OF MANAGEMENT \& PRODUCTION (IJM\&P)

http://www.ijmp.jor.br

v. 9, n. 1, January - March 2018

ISSN: 2236-269X

DOI: 10.14807/ijmp.v9i1.628

Bogor Regency is one of the locations of 197 regencies/cities that are made to be Minapolitan (fisheries cluster) by Ministry of Mariine Affairs and Fisheries. Bogor Regency is assigned three (3) main sub-districts as Minapolitan areas: Parung, Gunung Sindur and Ciseeng sub-districts. Minapolitan area in Bogor sub-district has a land area of about 2,592 hectares. The main commodities which are developed in this area include catfish, gouramy, and ornamental fish (DEPARTMENT OF ANIMAL LIVESTOCK AND FISHERIES BOGOR REGENCY, 2015). The detailed data can be seen in this table.

Table 1. Fishes production in Bogor (ton)

\begin{tabular}{llrrrr}
\hline \multicolumn{1}{c}{ Commodity } & \multicolumn{1}{c}{2010} & \multicolumn{1}{c}{2011} & \multicolumn{1}{c}{2012} & \multicolumn{1}{c}{2013} & \multicolumn{1}{c}{2014} \\
\hline Catfish & $24.884,52$ & $33.922,46$ & $47.733,14$ & $64.047,79$ & $79.640,83$ \\
Carp & $4.063,56$ & $9.042,50$ & $10.557,85$ & $9.241,72$ & $11.179,77$ \\
Tilapia & $2.073,37$ & $6.133,40$ & $6.585,95$ & $6.832,72$ & $8.095,41$ \\
Gouramy & $2.057,61$ & $2.340,00$ & $3.783,40$ & $4.065,40$ & $5.124,24$ \\
\hline
\end{tabular}

Source: Department of Animal Livestock and Fisheries Bogor Regency (2015)

Catfish production in Bogor tend to increases. In addition, the production was higher than other commodities. During 2010-2014, the average increase in production of catfish in Bogor Regency was approximately 30\%. The price of catfish was fluctuates, following the demand and supply conditions which are always changing. The price of catfish in Warta Pasar Ikan (fish price information website) (2016) ranged from IDR 15.000 - 20.000 in 2014-2016 for Bogor and the surrounding areas.

Although catfish has good business prospect, further analysis is required related to the value chain in this business. The indicative main problems of catfish farming is the high price of feed, which becomes the largest component of production costs. Cost for feed on catfish farming can reach $80 \%$ or more than the total cost of production (SUPRAPTO; SAMTAFSIR, 2013).

The value chain was first introduced by Porter in the mid 1980's as a concept to enhance competitiveness. In this concept, Porter divided business activities into two types of activity, namely primary and secondary. The primary activity is the core activities that can directly influence profits. Meanwhile, secondary activity is to support the main activity (PORTER, 1990).

Yusuf and Trondsen (2013) and Mwaijande (2015) reveal that the analysis of fisheries value chain can increase the competitiveness of farmers. Yusuf and 
Trondsen (2013) suggest the minapolitan as a strtaegy to strengthen Indonesian fisherman competitiveness. And Mwaijande (2015) suggest that strengthening partnership between farmers and private sectors could be a strategy to upgrade the fisheries value chain in Tanzania.

Trienekens (2011) formulated the concept of value chain analysis for developing countries. There are three components that can be identified in the analysis of the value chain in developing countries. Those three components include constraints in the value chain, and the elements of value chain.

\section{RESEARCH METHOD}

This research was conducted by survey method using questionnaire instrument. The survey was doneby using purposive sampling technique to 23 catfish farmers, 7 catfish wholesalers, 5 catfish retailers, and 5 catfish processors in Bogor Regency. Farmer respondents were selected in the production center in Parung, Gunung Sindur, and Ciseeng Sub-districts. All those three districts are the areas which are defined by the local government as the Minapolitan area.

The research was limited in the enlargement process of fish until to the sale process. Discussion is deepened in the on farm production. It is the most important part of catfish value chain as a whole. The catfish value chain was mapped by catfish flow from one actor to the other actors along the catfish supply chain.

The in-depht interview to farmers was done to identified the main problems of catfish production. Those problems became consideration to arrange the upgrading strategies to increase farmers competitiveness.

The quantitative data in this study were processed by using Microsoft Excel. The data which are used to draw conclusions are the mean, mode, and percentages. The qualitative data in discussion result with the actors are explained descriptively.

\section{RESULT AND DISCUSSIONS}

\subsection{Catfish Value Chain}

Based on the result of survey to the respondents from all actors involved in the value chain of catfish in Bogor Regency, the map of catfish value chain can be showed on Figure 1. There are five main processes along catfish value chain. The 
five processes are production input (seed, feed, and fish drugs), catfish production, wholesale, retail, and processing.

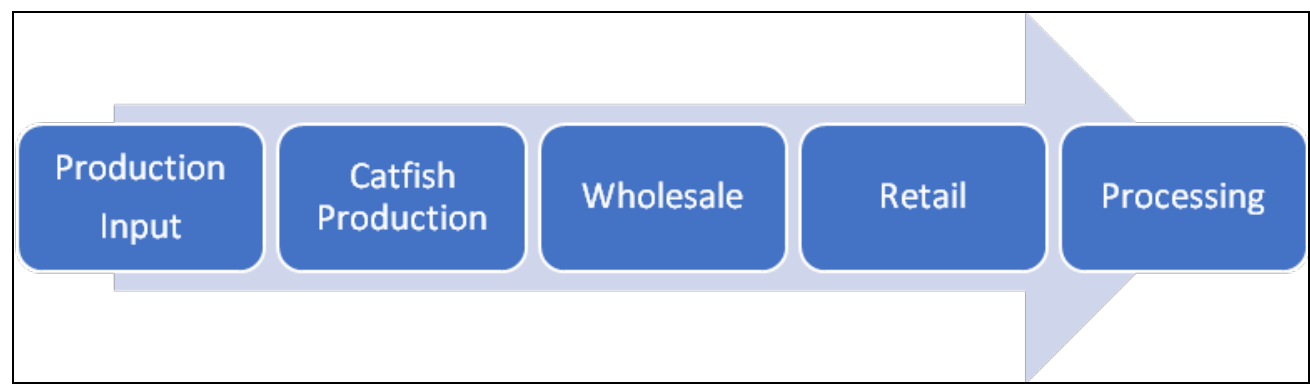

Figure 1: Catfish Value Chain in Bogor, Indonesia

Catfish value chain in Bogor has four types of channel. The channels were classified by flow of catfish from one actor to the other actors. The four of channels are explained below.

1. Farmers - Wholesalers - Retailer - Processor - Final consumer

2. Farmers - Wholesalers - Retailer - Household (final consumer)

3. Farmers - Wholesalers - Processor - Final consumer

4. Farmers - Household (final consumer)

Channel 1 is the longest channel which involves all of the existing actors. Final consumers in this channel are the visitors in restaurants that provide a menu of processed catfish. Chanel 2 involves three actors who produce live fish or fresh fish that has not been processed. Final consumer of this channel is household. The characteristic of Channel 3 is the farmer who sells fish produced directly to retailers without the intermediary of wholesalers. While the characteristic of Channel 3 is the fish farmer sell fish directly to the end consumer, which is household.

All fish farmers use Channel 1 as the main value chain channel. Channel 2, 3, and 4 only serve as the alternative channel. All channels of catfish value chain which are formed in Bogor Regency include in A-System of the value chain in developing countries introduced by Ruben et. al. (2007). This system has several characteristics such as many small farmers, large production with little added value, as well as the main market which is the local market with the middle-low segments.

\subsection{Value Chain Actors}

From the survey, there are four main actors of the catfish value chain in Bogor :farmers, wholesalers, retailers, and processors. Farmers, wholesalers, and retailers 
sell catfish which are alive or fresh. The processors sell catfish that have been processed into food which are sold in street food. All catfish which are produced is for the needs of the local market in Bogor and its surroundings, especially the market in capital city of Jakarta.

Farmers are the most important actors in the value chain of catfish. They produce catfish for consumption with the size 6-10 fish/ kg. Catfish seeds which are stocked at the beginning of have an average size $9-10 \mathrm{~cm}$. The measurement standard which is commonly used in catfish for consumption is the weight (kilograms).

While the measurement standard of catfish seeds used is body length $(\mathrm{cm})$. The average length of time which is required by farmers to produce catfish in the size of consumption is 63 days. However, most respondents, or as much as $82.61 \%$ produce their fish for 60 days with the general stocking density of $100 \mathrm{fish} / \mathrm{m} 3$ with an average mortality $9.7 \%$ (Table 2). Farmers buy catfish seeds with an average price IDR $241.5 /$ fish. The average selling price received by farmers is in an amount of IDR $16,8636 / \mathrm{kg}$.

Table 2: The activities of farmer of catfish

\begin{tabular}{lrrrrrr}
\hline Variables & mean & median & mode & $\%$ mode & max & min \\
\hline Time of production (day) & 63 & 60 & 60 & 82.6 & 90.0 & 60 \\
Density (fishes $/ \mathrm{m}^{2}$ ) & 113.9 & 100 & 100 & 82.6 & 178.6 & 90 \\
Mortality rate (\%) & 9.7 & 10 & 10 & 43.48 & 20 & 5 \\
Seeds price (IDR) & 241.5 & 250 & 250 & 47.8 & 300 & 200 \\
Catfish price (IDR) & $16,863.6$ & 17,000 & 17,000 & 47.8 & 18,000 & 16,000 \\
\hline
\end{tabular}

The next actor is wholesaler. Wholesalers are traders who buy fish from farmers. One respondent or $14.3 \%$ of the respondents buys catfish from farmers every day. A total of 4 collectors or $57.1 \%$ buy catfish every 2-3 days. And the remaining 3 collectors or $28.6 \%$ make a purchase once a week.

However, based on the information from farmers, as many as $73.9 \%$ of farmers sell catfish in the culture pond, as much as $21.7 \%$ of fish farmers deliver fish to the buyer, and $4.4 \%$ do both of them (Table 3). Nevertheless, all farmers sell their fish in the culture pond. Fish delivery to wholesalers is only performed as an alternative. The average selling price from wholesalers to the next actor is $21.000 /$ $\mathrm{kg}$. 
DOI: 10.14807/ijmp.v9i1.628

Table 3: Catfish buyer and its transportation

\begin{tabular}{llrr}
\hline & Buyer Information & Amount & Percentage \\
\hline Catfish buyer & Wholesaler & 23 & 100 \\
& Retailer & 1 & 4.4 \\
& Household & 3 & 13 \\
\multirow{3}{*}{ Distribution } & Other & 0 & 0 \\
& Pick up to consumer & 5 & 21.7 \\
& Picked up at pond & 17 & 73.9 \\
& Both & 1 & 4.4 \\
\hline
\end{tabular}

The next actor is retailer. Retailers are traders who get the fish from wholesalers. Retailers sell fish in smaller amounts but they sell various kinds of fish other than catfish, like tilapia, carp, and gouramy. Retailers have closer place to the final consumers such as households or the next actor. The average daily retail price is up to $38 \mathrm{~kg}$. The average selling prices of retailers to the final consumer or the next actor is IDR $25,000 / \mathrm{kg}$.

The last actor involved in the value chain of catfish is processor. Processor is meal sellers who sell catfish as one meal menu. Processor is the only actor who does not produce fresh catfish. So it can be said that processor is an actor who has a higher value added per fish. But when it is viewed from the purchase amount of catfish as the input is only 3-5 kg per day, or about 24-40 fish per day. The average selling price of catfish that has been processed into meal menu is IDR 10,000/fish.

\subsection{Characteristics of the Farmers}

Table 4 shows that all respondents of farmers are male. In this survey, there are no farmers are female. Based on the characteristics of age, dominance of the age of farmers is in the age interval of 31-40 years with a number of farmers as many as 12 people or $52.2 \%$ of total respondents. After that, $30.4 \%$ or 7 people aged $41-50$, and the rest is at less than 30 and over 50 years, respectively by $8.7 \%$ or as much as 2 people.

If it is viewed based on the characteristics of education, as many as 10 farmers, or $8.7 \%$ have completed their education up to senior high school, the last education of six farmers or $26.1 \%$ is junior high school, the last education of as much as 5 farmers or $21.7 \%$ is elementary school, and the remaining 2 farmers or $8.7 \%$ study up to university. 
DOI: 10.14807/ijmp.v9i1.628

Table 4: Human resources characteristic

\begin{tabular}{|c|c|c|c|}
\hline \multicolumn{2}{|c|}{ Farmer Characteristics } & \multicolumn{2}{|c|}{ Percentage (\%) } \\
\hline \multirow[t]{2}{*}{ Sex } & Male & 23 & 100.0 \\
\hline & Female & 0 & - \\
\hline \multirow[t]{4}{*}{ Age (years) } & $\leq 30$ & 2 & 8.7 \\
\hline & $31-40$ & 12 & 52.2 \\
\hline & $41-50$ & 7 & 30.4 \\
\hline & $>51$ & 2 & 8.7 \\
\hline \multirow[t]{4}{*}{ Education } & Elementary School & 5 & 21.7 \\
\hline & Junior High School & 6 & 26.1 \\
\hline & Senior High School & 10 & 43.5 \\
\hline & University & 2 & 8.7 \\
\hline \multirow[t]{2}{*}{ Livelihood } & Catfish farmer & 21 & 91.3 \\
\hline & Other & 2 & 8.7 \\
\hline \multirow[t]{4}{*}{$\begin{array}{l}\text { Length time to be farmer } \\
\text { (years) }\end{array}$} & $\leq 5$ & 4 & 17.4 \\
\hline & $6-15$ & 13 & 56.5 \\
\hline & $16-30$ & 5 & 21.7 \\
\hline & $>30$ & 1 & 4.3 \\
\hline \multirow[t]{2}{*}{ Catfish workshop } & Yes & 14 & 60.9 \\
\hline & No & 9 & 39.1 \\
\hline
\end{tabular}

Among all farmer respondents, there are 21 farmers or $91.1 \%$ make the catfish culture as the main livelihood. While the rest of the farmers have other jobs such as rice farmers and civil servants.

There is only one person or $4.3 \%$ who has become a farmer for more than 30 years. A total of five farmers or $21.7 \%$ have been doing catfish farming during $16-30$ years. As many as 13 people or $56.5 \%$ had undergone catfish farming during 6-15 years. And the remaining 4 people or $56.5 \%$ had been doing catfish farming for less than or equal to 5 years.

The entire farmers who are surveyed do not have the educational background which is related to fish farming, both catfish and other fish. Knowledge of fish farming is obtained from direct experience in the field. However, as many as 14 farmers or $60.9 \%$ had attended a short training on catfish farming which is organized by the government and feed company.

\subsection{Problems of the Value Chain}

There are some problems along the catfish value chain. The constraints can be grouped into three aspects: pre-production, production, and post-production constraints. 
INDEPENDENT JOURNAL OF MANAGEMENT \& PRODUCTION (IJM\&P)

http://www.ijmp.jor.br

v. 9, n. 1, January - March 2018

ISSN: 2236-269X

DOI: 10.14807/ijmp.v9i1.628

The main problem in the pre-production occurs in the procurement of raw material input, especially seeds and feed inputs. The main problem on the seeds is its quality, seeds supply sustainability and the uniformity of size. The quality of seeds obtained by the farmers does not have a basic standard. Catfish seeds are obtained from the farmers who do not have the same production standards.

The fluctuation of the quality of catfish can cause inconsistent enlargement of the production process. Thus, it allows farmers to produce catfish with inconsistent productivity as well.

Another issue on the pre-production is feed input. The problems mentioned on feed by farmers respectively are the more expensive feed prices, capital to purchase and unstable feed quality. The price of pellets produced by factory is considered expensive by the farmers. This is certainly a burden for the farmers because the cost of feed could reach $80 \%$ of all components of production costs (SUPRAPTO; SAMTAFSIR, 2013).

In overcoming the high price of feed, farmers use two ways, namely by combining the factory feed with alternative feed in the form of the waste of chicken eggs. However, the use of alternative feed in excessive amounts can decrease quality of the environment and threat sustainability of aquaculture. The second way is by delaying payments. For farmers who have greater capital capacity, they do direct cooperation with the feed company. This cooperation makes the farmers have a term of payment for 1 month. While farmers with middle to lower production scale, they anticipate it by making cooperation with the "nucleus farmers" who have access to direct cooperation with the feed company.

The last problem on pre-production is the access to capital. Respondents stated that they lack of capital to expand they business scale. There are only $30.4 \%$ famers have an access to the loan from banks. Meanwhile, farmers who have limitation access to banking overcome it by borrowing money from their relatives or to the nucleusfarmers if the yare incorporated in the core nucleus-plasma cooperation. This shortage of capital is felt mainly by farmers who have less than 15 units of pound.

The constraints during production faced by farmers are the weather, diseases, and security. Weather problems could be an obstacle which affect the second 
INDEPENDENT JOURNAL OF MANAGEMENT \& PRODUCTION (IJM\&P)

http://www.ijmp.jor.br

v. 9, n. 1, January - March 2018

ISSN: 2236-269X

DOI: 10.14807/ijmp.v9i1.628

constraint. High rainfall becomes a threat to farmers. On a rainy day, the appetite of catfish tend to be reduced so that the need for nutrition is not met properly. In that condition, catfish become more susceptible to disease. Social security constraints is a social problem which is faced by farmers. Theft of fish and pound inventory become a threat to farmers.

While the post-harvest constraints commonly faced by farmers is the unstable price. Farmer generally becomes the price taker, not as price maker. This is possible because the bargaining position of farmers is lower than the buyers (wholesalers or retailers). The bargaining position of traders (retailers and wholesalers) is higher because they have access to the market directly.

\subsection{Upgrading the Value Chain}

A good value chain in agribusiness can increase the competitiveness of farmers (YUSUF; TRONDSEN, 2013; MWAIJANDE, 2015; SUPRIATNA et. al. 2014). Porter (2009) provides recommendations to the government of Indonesia that one of the biggest potentials of Indonesia is a marine and fishery sector. One strategy to improve the competitiveness of the fishery sector is to use the cluster approach. Cluster in the aquaculture sector is known as minapolitan.

Yusuf and Trondsen (2013) adds that one of the factors of success of minapolitan approach in improving the competitiveness of fishery sector is a good value chain.

Minapolitan or fishery cluster in Bogor Regency has become a strength for catfish farmers. This cluster development should be continued by strengthening the partnerships among farmers and strengthening the partnerships between farmers and other strategic partners, such as wholesalers and retailers as well as the feed companies. There are two partnerships among farmers that can be selected by the farmers to have competitiveness, which is a partnership in the form of groups or cooperatives and partnerships in the form of nucleus-plasma.

Partnership of groups/cooperatives can improve the bargaining position of farmers, and allow it to become a price taker in the entire value chain. Farmers collectively can access the market by ensuring the supply sustainability of catfish production. For all this time, small farmers who stand alone have weak bargaining 
power and find a difficulty to access the market because they cannot supply the fish in a sustainable manner.

While the advantage of nucleus-plasma partnership is to reduce the capital expense during the production. Nucleus farmer will provide a capital guarantee of production inputs, such as catfish seeds and feed to the plasma. This capital can be paid by the plasma when the cycle has ended and fish has been sold. Nucleus farmers have high bargaining power to feed company for a large scale production. Nucleus farmers can make payment of feed to the company within 30 days. This allows farmers to rotate the capital for other production costs.

\section{CONCLUSION}

There are four main actors involved in the value chain of catfish in Bogor Regency. Those fourt actors include farmers, wholesalers, retailers, and processors. The constraint on the value chain of catfish in the Bogor Regency is divided into 3 parts. The problem of pre-productioninclude the quality of catfish seeds, high price of feed, and the lack of capital. Production problems include the weather, fish mortality, and social security.

As well as post-production problems that include price instability and the bargaining power of farmers against traders that is still weak. The main strategy to improve the competitiveness of farmers in the entire value chain is to strengthen the partnership among farmers and the partnerships between farmers and strategic partners, such as traders and feed company. This partnership can increase the bargaining power of farmers and can reduce the cost of production through feed and catfish seeds loans.

\section{REFERENCES}

CENTRAL BUREAU OF STATISTICS (2016). Sensus Pertanian 2013.

Available:http://www.st.2013.bps.go.id. Access: 25th July, 2016.

DEPARTMENT OF ANIMAL LIVESTOCK AND FISHERIES BOGOR REGENCY (2015). Profil kawasan minapolitan Kabupaten Bogor. Available: http://disnakan.bogorkab.go.id/. Access: 25th July, 2016.

DIRECTORATE GENERAL OF AQUACULTURE. (2015). Rancangan Renstra DJ PB 2015-2019. Jakarta: Direktorat Jenderal Perikanan Budidaya. Kementerian Kelautan dan Perikanan Republik Indonesia. 
MWAIJANDE, F. A.; LUGENDO, P. (2015) Fish farming value chain analysis: policy implications for transformations and robust growth in Tanzania. Journal of Rural an Community Development, v. 10, n. 2, p. 47-62.

PORTER, M. (1990). The Competitive Advantage of Nations. New York: The Free Press

RUBEN, R.; VAN BOEKEL, M.; VAN TILBURG, A.; TRIENEKENS, J. (2007) Governance for Quality in Tropical Food Chains. The Netherlands: Wageningen Acadamic Publishers.

SUPRAPTO; SAMTAFSIR, L. S. (2013) Biofloc-165 Rahasia Sukses Teknologi Budidaya Lele. Jakarta: Agro165.

SUPRIATNA, A.; HASCARYO, B.; WISUDO, S. H.; BASKORO, M.; NIKIJULUW, V. P. H. (2014) Model rantai nilai pengembangan perikanan tuna, tongkol, dan cakalang di Indonesia. JPHPI, v. 17, n. 2, p. 144-155

TRIENEKENS, J. H. (2011) Agricultural value chains in developing countries a framework for analysis. International Food and Agribusiness Management Association, v. 14, n. 2, p. 51-81.

IKAN, W. P. (2016). Harga ikan rata-rata di tingkat eceran (Rp/Kg). Available: http://www.wpi.kkp.go.id. Acces: 25th July, 2016.

YUSUF, M.; TRONDSEN, T. (2013) Improving Indonesia's competitiveness:

innovation, value chains and cluster-bases for realising the huge potential of marine ad fisheries. International Journal of Organizational Innovation, v. 6, n. 1, p. 111118. 